\title{
Drug Resistance of Mycobacterium iuberculosis isolated from Patients discovered in the Third National Tuberculosis Prevalence Survey in 1975 in Korea
}

\author{
Sang Jae Kim D Sc. and Sung. Chin Kim, M.D. \\ Korean Institute of Tuberculosis, Korean National Tuberculosis Association
}

-국문초록-

\section{제 3 차 결핵실태조사에서 분리한 결핵군의 \\ 각종 항결핵제에 대한 감수성에 관한 연구}

\author{
깁 상 재 ·김 성 진 \\ 대한결핵협회 결핵연구원
}

1975년에 실시한 제 3 차 전국결핵실태조사에서 분리한 인형균주 270 주에 대한 약제 감수성 검사(이차 약제 포함)를 실시하여 다음과 같은 성적을 얻었다.

1. 총 270 주의 약제 감수성검사 성적을 보면 단제 또는 그이상 약제에 대한 내성률은 $36.3 \%$ 이었고, 단제 $14.8 \%, 2$ 제 $13.0 \%, 3$ 제 전내성이 $8.5 \%$ 로 나타났으며 $\mathrm{INH}$ 단독 약제 내성률은 $12.6 \%$ 였다.

2. 피검자 270 명중 과거 복약사실이 없는 자는 179 명 $(66.3 \%)$ 인데 이 군의 단제 또는 그 이상 약제 내성률 즉 1 차 내성 률은 $16.2 \%$ 로 나타났다.

3. 남녀별 약재내성에서는 유의한 차이롤 보이지 않았으나 도시와 농촌의 약제내성은 도시가 $46.2 \%$, 농촌이 $30.1 \%$ 로서 도시에서 높았다. 특히 다제내성이 도시에서 높았다.

4. 엑스선 진단별 약제내성은 단제 또는 그이상 약제내성률에 있어서 경 증 $24.3 \%$, 중등증 $33.6 \%$, 중증 $62.5 \%$ 로 나타났다.

5. 과거 치료력이 없고 내성이생긴 환자(일차내성)의 연령별 내성율은 5-35세군이 $21.9 \%, 39 \sim 65$ 세 군 $16.3 \%$, 그리고 65 세 이상이 $6.1 \%$ 로써 최근감염 연령군인 저연령층에서 높게 나타났다.

6. 총 분리균 270 주의 각 이차 약제에 대한 내성율은 에탐부톨 $3.7 \%$, 리팜피신 $3.0 \%$, 카나마이신 $2.6 \%$, 카프레오마이신 $2.2 \%$, 에치오나마이드 $1.1 \%$, 바이오마이신 $1.1 \%$ 로 비교적 낮은 내성을 나타 내었다.

\section{INTRODUCTION}

The high prevalence of drug resistance has a double-edged meaning; it is associated with a high rate of treatment failure due

본 논문의 요지는 제 10 차 국제항결핵연맹 동부지역회의 학술대회에 서 발표하였음. to improper or ineffective chemotherapy service, and it also refers to a wide use of corresponding drugs. The information on the prevalence of drug resistance is necessary not only for planning the mass chemotherapy programme but also to evaluate in part the performance of the over all chemotherapy service programme. Particularly 
the prevalence of primary drug resistance has an important epidemiological significance. Therefore an investigation of the prevalence of drug resistance was one of the primary objectives in the last two surveys in 1965 and 1970 and continuation of this study is natural in the 1975 survey.

From the 3rd survey we found 130 smearpositive cases and, by culture examination, 270 positive cases. We have investigated the drug sensitivity of these 270 isolates and the results obtained are presented with a discussion, comparing these results to past data.

\section{MATERIALS and METHODS}

The Strains: In the survey, laryngeal swabs and sputum specimens were collected from 3736 individuals whose chest $\mathrm{X}$-rays showed some abnormality on field reading. Of these X-ray suspects, a number of the cases have been found to have normal chest $\mathrm{X}$-rays on subsequent central reading. However, all the specimens from 3,736 suspected patients were subjected by microscopy and culture examination. The culture technique employed in the survey was the oxalic acid method which had been introduced into the first survey according to the recommendations of WHO. Hower we examined the sputum specimens remaining after using the aforementioned procedure, by additional culture methods either by simple direct methods with 2,599 sputa or by concentration method with 729 sputa on $3 \%$ Ogawa, KIT or Löwenstein-Jensen medium. Animal inoculations using mice were done with 501 sputa. Smear and oxalic acid culture examination of 3,736 sputum specimens and 3,736 laryngeal swabs yielded 207 positive cases and additional culture examination and animal inoculation produced an additional 68 positive cases. The culture positive cases totaled 270. All of these isolates were confirmed as species of $M$. tuberculosis thru identification tests. These 270 isolates were subjected to this study. All cultures were maintained on L-J medium.

Concentrations of Antituberculous Drugs used : Drug concentrations used for H37Rv and test strains are shown in Table 1.

Drug Sensitivity Test: The sensitivity of

Table 1. Drugs and their concentrations ( $\mathrm{r} / \mathrm{mi}$ ) used.

\begin{tabular}{lcccccc}
\hline \hline \multicolumn{1}{c}{ Drugs } & \multicolumn{3}{c}{ For H37Rv } & \multicolumn{3}{c}{ For test strains } \\
\hline Isoniazid(INH) & 0.025 & 0.05 & 0.1 & 0.2 & 1 & 5 \\
p-Aminosalicylic acid(PAS) & 0,125 & 0.25 & 0.5 & 1 & 2 & 4 \\
Streptomycin (SM) & 2.5 & 5 & 10 & 10 & 20 & 40 \\
Kanamycin (KM) & 2.5 & 5 & 10 & 5 & 10 & 20 \\
Capreomycin (CM) & 5 & 10 & 20 & 10 & 20 & 40 \\
Viomycin (VM) & 10 & 20 & 40 & 20 & 40 & 80 \\
Ethionamide (1321) & 10 & 20 & 40 & 20 & 40 & 80 \\
Ethambutol (EB) & 0.315 & 0.625 & 1.25 & 0.625 & 1.25 & 2.5 \\
Cycloserine (CS) & 10 & 20 & 40 & 20 & 40 & 80 \\
Rifampin (RFP) & 2.5 & 5 & 10 & 5 & 10 & 20 \\
\hline
\end{tabular}


the organisms to varying drug concentrations was determined by the indirect test on the L-J medium. The test was performed by using subcultures from the primary isolation medium. A loopful of bacterial mass (about $1 \mathrm{mg}$ in wet weight) from a 2 to 3 weeks old growth on the L-J medium was placed in a $1 / 4 \mathrm{oz}$ bottle containing 6 glass beads $(2-3 \mathrm{~mm}$ in diameter) and $0.5 \mathrm{ml}$ of sterile distilled water and the bottle was vigorously shaken on a voltex mixer for 1 min. An additional $4.5 \mathrm{ml}$ of sterile distilled water was then added to this bacillary homogenate and a loopful of the suspension was inoculated onto the medium with a loop (3 $\mathrm{mm}$ external daimeter) made from nichrome wire (24 SWG) after coarse bacillary clumps settled out. The inoculated media were incubated at $37^{\circ} \mathrm{C}$ for 4 weeks. The presence of 20 or more colonies on the drug containing medium was taken as an indication that the strain is resistant. Interpretation of the test for the sensitivity to PAS and SM was made by the resistance-ratio, namely, the MIC of the test strain divided by the MIC of strain H37Rv. The sensitivity of INH and second line drugs was determined by the presence or absence of growth at the critical concentrations of each drug where strain $\mathrm{H} 37 \mathrm{Rv}$ did not grow. The critical concentrations for INH, EB, 1321, RFP, CM, KM, VM, and CS were 0.2, 1.25, $40,10,20,10,40$, and $20 \mathrm{r} / \mathrm{ml}$ respectively.

\section{RESULTS}

The resistance to standard drugs of 270 isolates has been shown in Table 2 and Figure 1 comparing the data of the 1975 . survey with those of the 1965 and 1970 sur-

Table 2. A Comparison of Drug Resistance Between the 1st, 2nd, and 3rd National Tuberculosis Prevalence Surveys.

\begin{tabular}{llccc}
\hline \hline & & \multicolumn{3}{c}{ Survey Year } \\
\cline { 3 - 5 } & & 1965 & 1970 & 1975 \\
\hline $\begin{array}{l}\text { Total Number of Cases Tested } \\
\text { Total Number of Resistant Cases-. }\end{array}$ & & 17 & 132 & 270 \\
\hline \multirow{2}{*}{$\begin{array}{l}\text { Resistant to One Drug } \\
\text { INH }\end{array}$} & PAS & $12(16.9)$ & $17(12.9)$ & $34(12.6)$ \\
& SM & $2(2.8)$ & $2(1.5)$ & $2(0.7)$ \\
& SUB-TOTAL & $7(9.9)$ & $2(1.5)$ & $4(1.5)$ \\
Resistant to Two Drugs & INH-PAS & $21(29.6)$ & $21(15.9)$ & $40(14.8)$ \\
\hline Resistant to Three Drugs & INH-SM & $2(2.8)$ & $7(5.3)$ & $18(6.7)$ \\
& SUB-TOTAL & $3(4.2)$ & $5(3.8)$ & $17(6.3)$ \\
Total Resistance to & INH-PAS-SM & $5(7.0)$ & $12(9.1)$ & $35(13.0)$ \\
\hline
\end{tabular}


Table 4 Drug Resistance of $M$. Tuber:ulosis Isolated from Patients with Previous Chemotherapy.

\begin{tabular}{|c|c|c|c|c|c|c|c|c|}
\hline Radiographic Finding & $\begin{array}{l}\text { Number } \\
\text { of Cases } \\
\text { Examined }\end{array}$ & $\begin{array}{l}\text { Total } \\
\text { Res:stant } \\
\text { Cases }\end{array}$ & $\mathrm{INH}$ & PAS & $\mathrm{SM}$ & $\begin{array}{l}\text { INH } \\
\text { PAS }\end{array}$ & $\begin{array}{l}\text { INH } \\
\text { SM }\end{array}$ & $\begin{array}{l}\text { INH } \\
\text { PAS } \\
\text { SM }\end{array}$ \\
\hline $\begin{array}{l}\text { Inactive Tuberculos:s } \\
\text { \& Others }\end{array}$ & 3 & $2(66.7)$ & 0 & 0 & 0 & 0 & $2(66.7)$ & 0 \\
\hline Minimal Tuberculosis & 10 & $8(80.0)$ & $6(60.0)$ & 0 & 0 & $1(10.0)$ & 0 & $1(10.0)$ \\
\hline $\begin{array}{l}\text { Moderately Advanced } \\
\text { Tuberculosis }\end{array}$ & 39 & $26(66.7)$ & $4(10.3)$ & $1(2.6)$ & $1(2.6)$ & $7(18.0)$ & $5(12.8)$ & $5(20.5)$ \\
\hline Far Advanced Tuberculosis & s 39 & $33(84.6)$ & $12(30.8)$ & 0 & 0 & $7(18.0)$ & $5(12.8)$ & $9(23.1)$ \\
\hline Total & 91 & $69(75.8)$ & $22(24.2)$ & $1(1.1)$ & $1(1.1)$ & $15(16.5)$ & $12(13.2)$ & $18(19.8)$ \\
\hline
\end{tabular}

Numbers in Parenthesis represent Percent.

Table 5. Drug Resistance of M. Tuberculosis Isolated from Patients without Previcus Chemctherapy.

\begin{tabular}{lllllllll}
\hline Radiographic Finding & $\begin{array}{l}\text { No. of } \\
\text { Cases } \\
\text { Examined }\end{array}$ & $\begin{array}{c}\text { Resistal } \\
\text { Cases }\end{array}$ & I NH & PAS & SM & $\begin{array}{l}\text { INH } \\
\text { PAS }\end{array}$ & $\begin{array}{c}\text { INH } \\
\text { S M }\end{array}$ & $\begin{array}{c}\text { INH } \\
\text { PAS } \\
\text { S M }\end{array}$ \\
\hline $\begin{array}{l}\text { Inactive Tuberculosis } \\
\quad \text { \& Others }\end{array}$ & 28 & $6(21.4)$ & $2(7.1)$ & 0 & 0 & $2(7.1)$ & $1(3.6)$ & $1(3.6)$ \\
Minimal Tuberculosis & 63 & $10(15.9)$ & $4(6.4)$ & $1(1.6)$ & $2(3.2)$ & 0 & $2(3.2)$ & $1(1.6)$ \\
M. A Tuberculosis & 71 & $11(15.5)$ & $6(8.5)$ & 0 & 0 & $1(1.4)$ & $2(2.8)$ & $2(2.8)$ \\
F. A Tuberculosis & 17 & $2(11.8)$ & 0 & 0 & $1(5.9)$ & 0 & 0 & $1(5.9)$ \\
\hline \multicolumn{1}{c}{ Total } & 179 & $29(16.2)$ & $12(6.7)$ & $1(0.6)$ & $3(1.7)$ & $3(1.7)$ & $5(2.8)$ & $5(2.8)$ \\
\hline
\end{tabular}

Numbers in Parenthesis represent Percent.

allel each other. Thus, as we expected, the more advanced the disease the higher the prevalence of drug resistance was found. In minimal tuberculosis single drug resistance was $17.6 \%$ but multiple-drug resistance was $6.8 \%$. However, a higher prevalence of multiple-drug resistance was observed in moderately or far advanced tuberculosis (22. $8 \%$ or $39.3 \%$ respectively) than those of single-drug resistance $(10.9 \%$ or $23.2 \%$ resectively).

Drug resistance of 91 isolates from patients having a history of previous chemotherapy was $75.8 \%$ as shown in Table 4 . Of these $49.5 \%$ were resistant to two or three drugs and $26.4 \%$ to one drug. There was no significant difference between the groups at varying stages of disease development.

Primary drug resistance of isolates from 179 patients who did not have antituberculous drugs previously was $16.2 \%$ as shown in Table 5. Single-drug resistance was $8.9 \%$ and resistance to two or three ârugs was 7. 3\%. Differences in primary drug resistance according to the extent of disease were no longer significant.

When the patients were groufed by age of 30 year intervals, 5-35, 36-65, and more than 65, Primary drug resistance in these groups showed significant differences as shown in Table 6. Within the 5-35, 36-65, and more than 65 age groups, $14(21.9 \%)$, 
Table 6. Primary Drug Resistance by Age Groups

\begin{tabular}{ccccccccc}
\hline \multirow{2}{*}{ Age groups $\begin{array}{c}\text { Total } \\
\text { number of } \\
\text { cases } \\
\text { tested }\end{array}$} & $\begin{array}{c}\text { Total } \\
\text { resistant } \\
\text { cases }\end{array}$ & & \multicolumn{7}{c}{ Resistant to } \\
\cline { 5 - 9 } & 64 & $14(21.9)$ & $5(7.8)$ & 0 & $1(1.6)$ & $1(1.6)$ & $4(6.3)$ & $3(4.7)$ \\
$5-35$ & 80 & $13(16.3)$ & $7(8.8)$ & $1(1.3)$ & $1(1.3)$ & $1(1.3)$ & $1(1.3)$ & $2(2.5)$ \\
$36-65$ & 33 & $2(6.1)$ & 0 & 0 & $1(3.0)$ & $1(3.0)$ & 0 & 0 \\
$>65$ & 179 & $29(16.2)$ & $12(6.7)$ & $1(0.6)$ & $3(1.7)$ & $3(1.7)$ & $5(2.8)$ & $5(2.8)$ \\
\hline
\end{tabular}

Numbers in parenthesis represent percent.

Table 7. A Comparison of Drug Resistance Between Urban and Rural Areas.

\begin{tabular}{|c|c|c|c|c|c|c|c|c|}
\hline \multirow[b]{2}{*}{ Areas } & \multirow{2}{*}{$\begin{array}{l}\text { Total } \\
\text { Cases } \\
\text { Tested }\end{array}$} & \multirow{2}{*}{$\begin{array}{c}\text { Total } \\
\text { Resistant } \\
\text { Cases }\end{array}$} & \multicolumn{6}{|c|}{ Resistant to } \\
\hline & & & I N H & PA S & $S M$ & $\begin{array}{l}\text { I N H } \\
\text { PAS }\end{array}$ & $\begin{array}{l}\text { SM } \\
\text { I N H }\end{array}$ & $\begin{array}{l}\text { I N H } \\
\text { PAS } \\
\text { S M }\end{array}$ \\
\hline Urban & 104 & $48(46.2)$ & $16(15.4)$ & 0 & $1(1.0)$ & $8(7.7)$ & $8(7.7)$ & $15(14.4)$ \\
\hline Rural & 166 & $50(30.1)$ & $18(10.8)$ & $2(1.2)$ & $3(1.8)$ & $10(6.0)$ & $9(5.4)$ & $8(4.8)$ \\
\hline Total & 270 & $98(36.3)$ & $34(12.6)$ & $2(0.7)$ & $4(1.5)$ & $18(6.7)$ & $17(6.3)$ & $23(8.5)$ \\
\hline
\end{tabular}

Table 8. A Comparison of Drug Resistance by Sex.

\begin{tabular}{lrlllllll}
\hline \hline Sex & $\begin{array}{l}\text { Total } \\
\text { Cases } \\
\text { Tested }\end{array}$ & $\begin{array}{l}\text { Total } \\
\text { Resistant } \\
\text { Cases }\end{array}$ & I N H & P A S & S M & $\begin{array}{l}\text { I N P } \\
\text { PAS }\end{array}$ & $\begin{array}{c}\text { I N S } \\
\text { S M }\end{array}$ & $\begin{array}{l}\text { I N A S } \\
\text { S M }\end{array}$ \\
\hline Male & 177 & $65(36.7)$ & $18(10.2)$ & $2(1.1)$ & $3(1.7)$ & $14(7.9)$ & $12(6.8)$ & $16(9.0)$ \\
Female & 93 & $33(35.5)$ & $16(17.2)$ & 0 & $1(1.1)$ & $4(4.3)$ & $5(5.4)$ & $7(7.5)$ \\
\hline Total & 270 & $98(36.3)$ & $34(12.6)$ & $2(0.7)$ & $4(1.5)$ & $18(6.7)$ & $17(6.3)$ & $23(8.5)$ \\
\hline
\end{tabular}

$13(16.3 \%)$, and $2(6.1 \%)$ showed resistance to one or more of the standard drugs respectively. Therefore, as the group age increased primary drug resistance decreased.

A comparison of drug resistance between urban and rural areas has been made as shown in Table 7. Drug resistance of urban patients was $46.2 \%$ (48) out of 104 cases and that of rural patients, $30.1 \%$ (50) out of 166 cases. The difference between two groups was significant ( $p 0.01$ ). There was no sta- tistically significant difference in single drug resistance between the two groups, but there was a significant difference (p 0.025) in two or three drug resistance $(29.8 \%$ in urban and $16.3 \%$ in rural).

Drug resistance comparing males and females is seen in Table 8. However, no significant difference has been recognized. 270 patients who are excreting tubercle bacilli have been grouped into 4 age groups of 15 year intervals and drug resistance in these 
Table 9. A Comparison of Drug Resistance by Age Groups. (with and without previous chemotherapy)

\begin{tabular}{ccccccccc}
\hline & & \multicolumn{5}{c}{ Resistant to } \\
\cline { 4 - 9 } Age Groups & $\begin{array}{c}\text { Total } \\
\text { Cases }\end{array}$ & $\begin{array}{c}\text { Total } \\
\text { Resistant }\end{array}$ & I N H & P A S & S M & $\begin{array}{c}\text { I N H } \\
\text { P A S }\end{array}$ & I N S & $\begin{array}{c}\text { I N H S } \\
\text { S M }\end{array}$ \\
\hline $5-19$ & 28 & $8(28.6)$ & $3(10.7)$ & 0 & 0 & $2(7.1)$ & 0 & $3(10.7)$ \\
$20-34$ & 58 & $27(46.6)$ & $11(19.0)$ & 0 & $1(1.7)$ & $3(5.2)$ & $5(8.6)$ & $7(12.1)$ \\
$35-49$ & 71 & $29(40.9)$ & $9(12.7)$ & 0 & $1(1.4)$ & $7(9.9)$ & $5(7.0)$ & $7(9.9)$ \\
50 & 113 & $34(30.1)$ & $11(9.7)$ & $2(1.8)$ & $2(1.8)$ & $6(5.3)$ & $7(6.2)$ & $6(5.3)$ \\
\hline Total & 270 & $98(36.3)$ & $34(12.6)$ & $2(0.7)$ & $4(1.5)$ & $18(6.7)$ & $17(6.3)$ & $23(8.5)$ \\
\hline
\end{tabular}

groups have been compared as shown in Table 9. Of the 28 the 5-19 age group or $28.6 \%$ were resistant to one or more of the standard drugs, $46.6 \%$ of the $20-34,40.9 \%$ of the $35-49$, and $30.1 \%$ of the over 50 age group, showed resistance. Differences between age groups were significant.

Drug resistances to second-line drugs have been investigated along with the standard drugs. Of 270 isolates $3.7 \%$ were resistant to ethambutol, $3.0 \%$ to rifampin, $2.6 \%$ to kanamycin, $2.2 \%$ to capreomycin, $1.1 \%$ to ethionamide, and $1.1 \%$ to viomycin.

\section{DISCUSSION}

The prevalence of single and multipledrug resistance to the standard drugs in patients discovered in the three surveys in 1965, 1970, and 1975 showed observable trends. There was no substantial increase or decrease in total resistance between the three surveys. However, the prevalence of resistance to single or multiple drugs showed differing trends during the three survey years. For example the resistance to a single standard drug has shown a decrease in the 1970 survey when compared with that of the 1965 survey, but remained stationary between the 1970 and 1975 surveys. However, the resistance to two or three drugs had increased in the 1970 survey when ccmpared with that of the 1965 survey, but again remained stationary ketween the 1970 and 1975 surveys. This phencmena suggests that before 1965 single-drug regimen might have been used widely or a wide use of combined therapy was of an initial stage. Since 1962 at which the national tukerculosis programme was initiated, ccmbired therapy has been used widely. In comparing total resistance to each of the standard drugs the resistance to INH and PAS had clearly increased in the 1970 survey, but has since remained unchanged. However there was no significant difference in $S M$ resistance between the three surveys. This phencmena suggests a wide distribution of INH and PAS since 1962 when the NTP was first initiated.

If the chemotherapy prcgramme is implemented effectively, the primary drug resistance will decrease due to successful regative conversicn of positive cases, Thus no drug resistant bacilli can be evolved and transmitted to the community. The absence of differences in the prevalence of drug resistance between the 1970 and 1975 surveys 
reflect in part no difference in the over all treatment services during that time. The effeztiveness of a chemotherapy service programme can also be estimated by observing the prevalence of primary drug resistance because usually the prevalence of primary drux resistanse in developing countries is higher than in technically developed countries suggesting ineffective treatment survices in the former than in the latter. In the 1975 survey primary drug resistance has been found to be $16.2 \%$ which is still high enough to suggest a high prevalence of drug resistant cases in the pool of positive cases. This figure is also comparable with those of other developing countries but not with those of teshnically developed countries. This figure can not be compared directly with $23.9 \%$ of the 1970 survey because many of the cases found during the survey as having no history of previous chemotherapy were reconfirmed and many of these cases had previous chemotherapy, however, such rezonfirmation data was not gathered in the 1970 survey. Drug resistant organisms usually evolve as a result of failure of initial drug therapy, thus, reduction of such cases thru improvement of treatment service will cause a decrease in the prevalence of primary drug resistance.

The higher prevalence of drug resistance in urban patients than in rural patients suggests that urban patients have a greater accessibility to these drugs than do rural patients. The factors affecting the lower rate of drug resistance in the less than 19 and the over 50 years old age groups than those in the other groups are rather unclear. However $14.3 \%$ and $21.2 \%$ of patients had a history of chemotherapy in the less than
19 and the over 50 age groups while $36.2 \%$ and $26.8 \%$ of patients had a history of chemotherapy in the 20-34 and the 35-49 age groups respectively. These suggest that the proportion of patients having a history of previous chemotherapy seem to be closely related to the prevalence of drug resistance.

The prevalence of resistance to second-line drugs is not a matter of grave concern yet, therefore, we can introduce these drugs into the mass chemotherapy programme to strengthen the drug regimen.

\section{SUMMARY}

The sensitivity to standard and secondline antituberculous drugs has been investigated on 270 isolates of $M$. tuberculosis which were obtained from patients discovered in the 3rd national tuberculosis prevalence survey in 1975 in Korea. The results obtained are as follows.

1. Of 270 isolates $36.3 \%$ were resistant to one or more of the standard drugs. The resistance to one drug was $14.8 \%$ and of these the resistance to INH alone was $12.6 \%$. The resistance to two or all three drugs was $13.0 \%$ or $8.5 \%$ respectively.

2. Of 179 isolates from patients without previous chemotherapy $16.2 \%$ were resistant to one or more of the standard druge.

3. There was no significant difference in drug resistance between males and females, however, significant differences have been observed between urban and rural patients as the resistance of the former was $46.2 \%$ while that of the latter was $30.1 \%$. The difference is mainly due to a larger prevalence of resistance to two or three drugs in urban areas than that in rural areas. 
4. The drug resistance accordiing to extent of disease was $24.3 \%$ in minimal tuberculosis, $33.6 \%$ in moderately advanced tuberculosis, and $62.5 \%$ in far advanced tuberculosis.

5. Drug resistance of age groups less than 19 and over 50 years $(28.6 \%$ and $30.1 \%$ respectively) were significantly lower than those for age groups $20-34$ and $35-49(46.6 \%$ and $40.9 \%$ respectively).

6. Of 270 isolates $3.7 \%$ were resistant to ethambutol, $3.0 \%$ to rifampin, $2.6 \%$ to kanamycin, $2.2 \%$ to capreomycin, $1.1 \%$ to ethionamide, and $1.1 \%$ to viomycin.

\section{REFERENCES}

1. Kim, S. C., Kim, S. J., and Lee, K. J. Drug resistance of $M$. iuberculosis isolated from patients discovercd in the second national tuberculosis prevalence survey. Tuberculosis and Respiratory Diseases (Korean) 21 (2) :85-95, 1974.

2. Kim, S. C. Primary drug resistance of $\mathrm{MycO}-$ bacterium tuberculosis isolated from untreated patients with pulmonary tuberculosis in Korea Kekkaku 46(5):165-171, 1971.

3. Jin, B.W. A study of drug resistance (acquired and primary) in newly registered infectious tuberculosis patients in Seoul city(JuneDecember 1971). Tuberculosis and Respiratory Diseases (Korean) 22(1):5-10, 1975.

4. Canetti, G. et al. Mycobacteria: laboratory. methods for testing drug sensitivity and resistance. Bull. WHO, 29:595-578, 1963.

5. Kim, S. J. and Kim, S. C. Isolation of a strain of Mycobacterium tuberculosis sensitive to penicillin. Tubercnosis and Respiratory Diseases (Korean) 23(1):6-12, 1976. 